\title{
UPAYA PENINGKATAN AKTIFITAS DAN PRESTASI BELAJAR SISWA SMAN 3 TEBO MELALUI MODEL PEMBELAJARAN TIPE NUMBERED HEAD TOGETHER PADA MATERI SISTEM EKONOMI
}

\author{
FITRIWATI \\ SMA Negeri 3 Tebo Provinsi Jambi \\ fitriwatiardi@yahoo.co.id
}

\begin{abstract}
ABSTRAK
Penelitian ini bertujuan untuk meningkatkan aktifitas dan prestasi belajar ekonomi materi sistem ekonomi melalui pelaksanaan pembelajaran kooperatif tipe Numbered Head Together (NHT). Adapun yang menjadi subjek penelitan ini adalah siswa kelas X IPS 3 SMA Negeri 3 Tebo tahun pelajaran 2019/2020 yang berjumlah 36 orang terdiri dari 16 laki-laki dan 20 perempuan. Penelitian ini merupakan penelitian tindakan kelas (PTK) yang terdiri dari dua siklus dan setiap siklus terdiri atas empat tahapan yaitu perencanaan, pelaksanaan tindakan, pengamatan dan refleksi. Pelaksanaan proses penelitian dilakukan dalam dua kali pertemuan tiap siklus. Dan setiap siklus diadakan refleksi terhadap proses pembelajaran dengan memperhatikan kekurangan-kekurangan yang ada pada siklus I, maka perlu diadakan beberapa perbaikan pada siklus ke II. Teknik pengumpulan data dilakukan dengan melakukan observasi, menggunakan tes, dan dokumentasi. Alat pengumpulan data yang digunakan dalam penelitian ini adalah lembar observasi aktivitas siswa, dan soal tes objektif. Analisis data dilakukan dengan analisis kualitatif dan kuantitatif. Hasil penelitian menunjukkan bahwa pada siklus I, siswa yang memperoleh nilai 65 ke atas jumlahnya 24 atau 66,67\% dan yang memperoleh nilai 65 ke bawah jumlahnya 11 orang atau 33,33\%, sedangkan pada siklus II, siswa yang memperoleh nilai 65 ke atas jumlahnya menjadi 29 orang atau 80,95\% dan yang memperoleh nilai 65 ke bawah jumlahnya 7 orang atau 19,05\%. Berdasarkan hasil penelitian ini dapat disimpulkan bahwa prestasi belajar ekonomi siswa kelas X IPS 3 SMA Negeri 3 Tebo pada materi sistem ekonomi dapat meningkat melalui penerapan pembelajaran kooperatif tipe Numbered Head Together (NHT).
\end{abstract}

Kata Kunci: aktifitas siswa, prestasi belajar siswa, system ekonomi, model pembelajaran tipe Numbered Head Together (NHT).

\section{ABSTRACT}

This study aims to increase the activity and achievement of learning economics on economic system materials through the implementation of Numbered Head Together (NHT) cooperative learning. The subjects of this research were students of class X IPS 3 at SMA Negeri 3 Tebo for the academic year 2019/2020, totaling 36 people consisting of 16 males and 20 females. This research is a classroom action research (CAR) which consists of two cycles and each cycle consists of four stages, namely planning, implementing actions, observing and reflecting. The implementation of the research process was carried out in two meetings in each cycle. And every cycle there is a reflection on the learning process by paying attention to the shortcomings that exist in the first cycle, it is necessary to make some improvements in the second cycle. Data collection techniques were carried out by observing, using tests, and documentation. Data collection tools used in this study were student activity observation sheets, and objective test questions. Data analysis was carried out by qualitative and quantitative analysis. The results showed that in the first cycle, students who scored 65 and above were 24 or $66.67 \%$ and those who scored 65 and under were 11 people or $33.33 \%$, while in the second cycle, students who scored 65 and above. the number is 29 people or $80.95 \%$ and those who get a score of 65 and below are 7 people or $19.05 \%$. Based on the results of this study, it can be concluded that the economic learning achievement of students in class X IPS 3 at SMA Negeri 3 Tebo on the material of the economic system can be increased through the application of Numbered Head Together (NHT) cooperative learning. 
Keywords: student activity, student achievement, economic system, Numbered Head Together (NHT) type of learning model.

\section{PENDAHULUAN}

Pendidikan sekolah merupakan pendidikan formal yang memegang peranan penting dalam menentukan suatu bangsa. Pendidikan sekolah mempunyai mata rantai yang berhubungan dengan kehidupan manusia. Pendidikan sebagai proses upaya meningkatkan nilai peradaban individu dari keadaan tertentu kesuatu keadaan yang lebih baik, secara institusional peranan dan fungsinya semakin dirasakan oleh sebagian besar warga bangsa. Proses pembelajaran merupakan suatu proses yang mengandung serangkaian perbuatan guru dan siswa atas dasar hubungan timbal balik yang berlangsung dalam situasi edukatif untuk mencapai tujuan tertentu" Proses pembelajaran merupakan interaksi semua komponen atau unsur yang terdapat dalam pembelajaran yang satu sama lain saling berhubungan dalam sebuah rangkaian untuk mencapai tujuan. Pendidikan nasional berfungsi mengembangkan kemampuan dan membentuk watak serta peradaban bangsa yang bermartabat dalam rangka mencerdaskan kehidupan bangsa, bertujuan untuk berkembangnya potensi siswa agar menjadi manusia yang beriman dan bertakwa kepada Tuhan Yang Maha Esa, berakhlak mulia, sehat, berilmu, cakap, kreatif, mandiri dan menjadi warga negara yang demokratis serta bertanggung jawab (Hasibuan, dkk, 2018).

Dalam upaya mencapai tujuan tersebut di atas, Guru memiliki peranan yang sangat penting. Kedudukan Guru dan Dosen sebagai tenaga professional bertujuan untuk melaksanakan sistem pendidikan nasional dan mewujudkan tujuan pendidikan nasional (Seknun, 2018). Guru merupakan pilar utama pendidikan. Peran guru sangat strategis dalam perkembangan kemajuan pendidikan di negara manapun. Keberhasilan pendidikan berada di tangan para guru. Guru merupakan faktor yang mempengaruhi berhasil atau tidaknya proses belajar mengajar, dan karenanya guru harus menguasai prinsip-prinsip belajar disamping menguasai materi yang akan diajarkan dengan kata lain guru harus mampu menciptakan suatu kegiatan belajar mengajar yang sebaik-baiknya (Manizar, 2015).

Untuk meningkatkan prestasi belajar, guru hendaknya meningkatkan kualitas pembelajaran yang semula berpusat pada guru beralih berpusat pada murid; metodologi yang semula didominasi ekspositori. berganti kepartisipatori; dan pendekatan yang semula bersifat tekstual berubah menjadi kontekstual. Semua perubahan tersebut dimaksudkan untuk memperbaiki mutu pendidikan baik dari segi proses maupun hasil pendidikan. Kompetensi paedogogik adalah kemampuan guru mengelola pembelajaran siswa, kompetensi kepribadian adalah kemampuan kepriadian yang mantap, berakhlak mulia, arif, dan berwibawa serta menjadi teladan peserta lain; yang dimaksud kompetensi profesional adalah kemampuan guru dalam penguasaan materi pelajaran secara luas dan mendalam dan yang dimaksud dengan kompetensi soaial adalah kemampuan guru untuk berkomunikasi dan berinteraksi secara efektif dan efisien dengan siswa, sesama guru, orang tua/wali siswa dan masyarakat sekitar (Susilo, dkk, 2016).

Idealnya, proses pembelajaran tidak hanya diarahkan pada upaya mendapatkan pengetahuan sebanyak-banyaknya, tetapi juga mengembangkan kemampuan siswa untuk berinteraksi sosial mengakui perbedaan pendapat, menerima saran dari teman lain yang mempunyai kemampuan berpikir dan cara pandang yang berbeda terhadab materi yang sedang dipelajari (Mastika, dkk, 2014).

Dalam penggunaan model pembelajaran Cooperative Learning perlu di pahami agar dapat melaksanakan pembelajaran secara efektif dalam meningkatkan hasil belajar. Dalam penerapan model pembelajaran memiliki tujuan, prinsip dan tekanan utama yang berbeda-beda dalam suatu model pembelajaran (Sudarsana, 2018). Pembelajaran kooperatif dikembangkan untuk mendorong siswa belajar bekerja sama dalam menyelesaikan tugas-tugas kelompok, mampu menerima keberagaman, dan mengembangkan keterampilan sosial. 
Berdasarkan observasi yang dilakukan di SMA Negeri 3 Tebo, dimana merupakan tempat peneliti mengajar, dari semua siswa di kelas $\mathrm{X}$ masih banyak siswa yang nilai hasil belajarnya terutama pada pelajaran Ekonomi masih di bawah Kriteria Ketuntasan Minimal (KKM) sebesar 75. Didapatkan kondisi bahwa siswa tidak bersemangat dalam kegiatan pembelajaran di kelas. Guru sudah mencoba menerapkan beberapa metode yang dianggap dapat meningkatkan aktifitas dan prestasi belajar siswa, kondisi hal tersebut tidak berdampak signifikan bagi perkembangan siswa. Hal tersebut menjadi dasar peneliti melakukan kegiatan penelitian dengan harapan ada perubahan kea rah yang lebih baik bagi siswa dan guru.

Agar dapat keluar dari permasalahan di atas, maka peneliti akan menggunakan model pembelajaran kooperatif dalam melaksanakan praktik pembelajaran. Model pembelajaran ini, mengutamakan adanya kerjasama antar siswa dalam kelompok untuk mencapai tujuan pembelajaran. Para siswa dibagi ke dalam kelompok-kelompok kecil dan diarahkan untuk mempelajari materi pelajaran yang telah ditentukan (Purnomo, dkk, 2017). Tujuan dibentuknya kelompok kooperatif adalah untuk memberikan kesempatan kepada siswa agar dapat terlibat secara aktif dalam proses berpikir dalam kegiatan belajar. Dalam hal ini, sebagian besar aktifitas pembelajaran berpusat pada siswa, yakni mempelajari materi pelajaran serta berdiskusi untuk memecahkan masalah. Salah satu model pembelajaran kooperatif yang peneliti pilih adalah tipe NHT (Numbered Heads Together). Pemilihan model pembelajaran tersebut, didasarkan oleh adanya penelitian terdahulu yang menemukan bahwa model ini dapat meningkatkan hasil belajar siswa.

Langkah perbaikan dalam pembelajaran yang dapat dilakukan salah satunya adalah dengan memilih model pembelajaran yang tepat, yaitu model pembelajaran kooperatif. Banyak tipe model kooperatif yang dapat digunakan, antara lain model pembelajaran kooperatif tipe NHT (Numbered Head Together). NHT merupakan salah satu tipe dari model pembelajaran kooperatif, yang melibatkan para siswa dalam melihat kembali bahan yang tercakup dalam suatu pembelajaran dan memeriksa pemahaman siswa mengenai isi pelajaran tersebut (Sofyan, dkk, 2018).

Sebagai model pembelajaran, NHT sangat berguna untuk memeriksa pemahaman konsep siswa. Model pembelajaran kooperatif tipe NHT merupakan model pembelajaran yang memungkinkan siswa lebih aktif dan bertanggung jawab untuk memahami materi yang akan dipelajari baik secara individu maupun kelompok. Hal ini dikarenakan pada tahap terakhir dalam model ini, siswa akan ditunjuk secara acak untuk dapat mempresentasikan hasil diskusi kelompoknya yang berkaitan dengan materi yang diajarkan (Dewi, dkk, 2017).

NHT digunakan untuk melibatkan lebih banyak siswa dalam menelaah materi yang tercakup dalam suatu pelajaran dan mengecek pemahaman mereka terhadap isi pelajaran tersebut. NHT sebagai model pembelajaran pada dasarnya merupakan sebuah variasi diskusi kelompok. Adapun ciri khas dari NHT adalah guru hanya menunjuk seorang siswa yang mewakili kelompoknya. Dalam menujuk siswa tersebut, guru tanpa memberi tahu terlebih dahulu siapa yang akan mewakili kelompok tersebut. NHT merupakan tipe pembelajaran kooperatif yang terdiri atas empat tahap yang digunakan untuk mereview fakta-fakta dan informasi dasar yang berfungsi untuk mengatur interaksi siswa (Indraswati, 2018).

Model pembelajaran NHT memberi kesempatan kepada siswa untuk membagikan ideide dan mempertimbangkan jawaban yang paling tepat. Adapun tahapan dalam pembelajan NHT antara lain yaitu penomoran, mengajukan pertanyaan, berfikir bersama, dan menjawab. Tahap 1 penomoran. Guru membagi siswa ke dalam kelompok beranggotakan 7 orang dan setiap anggota kelompok diberi nomor 1-7. Tahap 2 mengajukan pertanyaan Guru mengajukan sebuah pertanyaan kepada siswa. Pertanyaan dapat bervariasi, pertanyaan dapat spesifik dan dalam bentuk kalimat tanya atau bentuk arahan. Tahap 3 berpikir bersama siswa menyatukan pendapatnya terhadap jawaban pertanyaan itu dan meyakinkan tiap anggota dalam timnya mengetahui jawaban itu. Tahap 4 menjawab. Guru memanggil siswa dengan nomor tertentu, kemudian siswa yang nomornya sesuai mengacungkan tangannya dan mencoba untuk menjawab pertanyaan untuk seluruh kelas (Rofiqoh, dkk, 2015). 
Materi masalah ekonomi di SMA dipandang sangat relevan disampaikan melalui kegiatan pembelajaran dengan tehnik Numbered Head Together (NHT) sehingga siswa diharapkan lebih mampu mengembangkan potensi diri dan bisa belajar melalui kerja sama dalam kelompok. Bersamaan dengan pelaksanaan pembelajaran tersebut kami juga mengadakan Penelitian Tindakan Kelas (Lagur, dkk, 2018).

Oleh karena itu, peneliti tertarik melaksanakan kegiatan penelitian ini yang berjudul "Upaya Peningkatan Aktifitas dan Prestasi Belajar Siswa SMA Negeri 3 Tebo Melalui Model Pembelajaran Tipe Numbered Head Together Pada Materi Sistem Ekonomi"

\section{METODE PENELITIAN}

Penelitian ini merupakan Penelitian Tindakan Kelas (PTK) atau Classroom Action Research. Sesuai dengan karakteristik PTK, menurut Kemmis and Taggart maka penelitian ini terdiri atas dua siklus. Tiap siklus terdiri dari 4 tahap yaitu: (1) Perencanaan, (2) Pelaksanaan tindakan, (3) Observasi (pengamatan), dan (4) Refleksi. Dalam penelitian ini dilakukan 2 kali pertemuan dalam setiap siklus.

Penelitian ini dilaksanakan di kelas X IPS 3 SMA Negeri 3 Tebo. Alasan dipilihnya sekolah ini sebagai tempat penelitian adalah karena peneliti merupakan guru mata pelajaran ekonomi di sekolah tersebut. Penelitian ini dilaksanakan kurang lebih selama tiga bulan sejak mulai mulai dari bulan September sampai dengan November 2019.

Subyek dalam PTK ini adalah siswa kelas X IPS 3, di SMA Negeri 3 Tebo tahun pelajaran 2019/2020. Penentuan kelas ini dilaksanakan peneliti berdasarkan hasil investigasi terhadap kelas yang diajar oleh peneliti.

Pengumpulan data yang digunakan dalam PTK ini dilperoleh melalui beberapa cara, yaitu lembar observasi untuk aktivitas siswa dan kinerja guru selama pelaksanaan tindakan, serta soal pretes dan postes. Validasi proses pembelajaran dilakukan dengan teknik triangulasi yang meliputi yaitu triangulasi sumber dan triangulasi metode. Triangulasi sumber dilakukan dengan observasi terhadap subjek penelitian yaitu siswa kelas X IPS 3 SMA Negeri 3 Tebo dan kolaborasi dengan guru lain. Triangulasi metode dilakukan dengan penggunaan metode observasi. Validasi data untuk lembar observasi yang telah disediakan sebelumnya berupa tanda cek $(\sqrt{ })$ sehingga terlihat hasil berupa kegagalan dan keberhasilan pada pembelajaran yang telah dilaksanakan. Validasi prestasi hasil belajar dilakukan pada instrumen penelitian yang berupa tes. Analisis data yang digunakan dalam penelitian ini adalah teknik analisis deskriptif kualitatif dan kuantitatif.

\section{HASIL DAN PEMBAHASAN}

Hasil penelitian yang akan dibahas yaitu aktivitas belajar siswa pada saat proses pembelajaran berlangsung, dan prestasi hasil belajar siswa yang diperoleh pada setiap siklus yaitu siklus I dan siklus II.

Tabel 1 Data Hasil Observasi Aktivitas Siswa pada Siklus I dan II

\begin{tabular}{lll}
\multicolumn{1}{c}{ Aspek yang Diamati } & Rata-rata siklus \\
$\begin{array}{l}\text { 1. Siswa mendengar dan merespon apersepsi dan } \\
\text { motivasi yang disampaikan oleh guru }\end{array}$ & $\mathbf{1}$ & $\mathbf{2}$ \\
$\begin{array}{l}\text { 2. Siswa mendengarkan tujuan pembelajaran yang } \\
\text { disampaikan oleh guru }\end{array}$ & 2.5 & 3,5 \\
$\begin{array}{l}\text { 3. Siswa mendengarkan penjelasan langkah-langkah } \\
\text { pembelajaran kooperatif tipe Numbered Head } \\
\text { Together yang akan diterapkan. }\end{array}$ & 2,5 & 3 \\
\hline
\end{tabular}


4. Siswa mendengarkan penjelasan guru tentang materi pelajaran.

5. Siswa membentuk kelompok belajar sesuai petunjuk guru.

6. Siswa mengerjakan LKS ecara berkelompok.

7. Siswa mendiskusikan materi yang menjadi tugas kelompok.

8. Siswa mempresentasikan hasil kerja kelompoknya.

9. Siswa menyimpulkan materi pelajaran.

Jumlah skor perolehan

Skor maksimal

Persentase (\%)

Kriteria
3

2,5

2,5

2,5

2,5

2

22,5

36

$62,5 \%$

Cukup aktif
4

3

30

36

$83,33 \%$

Sangat aktif

Adapun Data ketuntasan belajar prestasi hasil tes pada siklus I dan II dapat dilihat pada tabel berikut:

Tabel 2 Prestasi Hasil Belajar Siswa Pada Siklus I dan II

\begin{tabular}{lcc}
\multicolumn{1}{c}{ Hasil belajar } & Siklus I & Siklus II \\
Jumlah siswa yang mencapai ketuntasan & 14 & 17 \\
Nilai rata-rata kelas & 64,05 & 70,24 \\
Persentas ketuntasan klasikal & $66,67 \%$ & $80,95 \%$ \\
\hline
\end{tabular}

Dari tabel di atas menunjukkan bahwa pada siklus II secara klasikal siswa sudah tuntas belajar, karena siswa yang memperoleh nilai $\geq 65$ sebesar $80,95 \%$ lebih besar dari prosentase ketuntasan yang dikehendaki yaitu sebesar $75 \%$. Hal ini menunjukkan bahwa pada siklus II ketuntasan belajar siswa sudah lebih meningkat dari siklus I.

\section{Pembahasan}

\section{Aktifitas Belajar Siswa}

Penerapan model pembelajaran kooperatif tipe Numbered Head Together (NHT) pada siklus I telah menunjukkan adanya peningkatan pada beberapa item aktivitas belajar yang diamati, diantaranya siswa yang meminta bimbingan kepada guru dalam menyelesaikan tugas dalam LKS, kerjasama dalam kelompok saat mengerjakan tugas, siswa memberi respon positif (mengangkat tangan dan/atau menjawab) atas pertanyaan yang telah ditanyakan guru pada fase menjawab pertanyaan. Namun setelah dirata-ratakan pertemuan pertama dan kedua pada siklus I ternyata belum memenuhi indikator pencapaian yang dikehendaki dalam penelitian ini yaitu 75\%. Pada siklus I dalam penelitian ini, masih ditemukan beberapa masalah dalam proses pembelajaran di kelas. Diantaranya siswa belum bisa memahami aturan main model pembelajaran yang diterapkan, sehingga guru kesulitan dalam mengelola kelas. Siswa belum antusias menyimak dan mencatat materi pelajaran yang disampaikan guru, sebagian siswa belum berani bertanya kepada guru dan menjawab pertanyaan guru tentang materi pembelajaran. Keaktifan masih didominasi oleh beberapa siswa dalam kelompok tersebut. Hal ini terbukti dari nilai kelompok dan individu siswa pada siklus I yang masih rendah. Masalahmasalah yang ditemukan tersebut selanjutnya dijadikan sebagai refleksi untuk perbaikan tindakan pada siklus II. 
Dalam upaya mengatasi masalah-masalah pada siklus I peneliti mengadakan perbaikan tindakan dalam siklus II. Dalam hal ini ditekankan pada pengelolaan kelas agar siswa yang aktif selama proses pembelajaran lebih meningkat. Siklus II dilaksanakan setelah merefleksi pelaksanaan siklus I sehingga diperoleh gambaran tindakan yang akan dilaksanakan pada siklus II sebagai perbaikan dari siklus I dan diharapkan aktivitas belajar siswa yang diperoleh sesuai dengan yang diharapkan atau mencapai indikator keberhasilan yang telah ditentukan. Perubahan yang dilakukan pada siklus II yang merujuk pada refleksi di siklus I ternyata sangat efektif dalam meningkatkan aktivitas belajar siswa. Hal ini dibuktikan dengan nilai persentase rata-rata seluruh aktivitas yang diamati meningkat dari $62,5 \%$ pada siklus I menjadi $83,33 \%$ pada siklus II dan telah memenuhi kriteria indikator keberhasilan yang telah ditetapkan dalam penelitian ini. Melihat aktivitas belajar siswa yang telah meningkat pada siklus II dan telah memenuhi indikator pencapaian, ternyata juga berdampak pada peningkatan hasil belajar.

\section{Prestasi Belajar Siswa}

Peneliti melakukan tes pada setiap akhir siklus untuk mengetahui ketuntasan hasil belajar siswa. Dari analisis terhadap tes tersebut diperoleh hasil yang sangat memuaskan, yaitu terjadi peningkatan hasil belajar siswa dari siklus I ke siklus II. Hasil tes pada siklus I dengan model pembelajaran kooperatif tipeGroup Investigation terjadi peningkatan dibandingkan nilai kondisi awal yaitu terdapat 24 siswa yang tuntas atau sebesar 66,67\% dari 36 jumlah siswa. Hasil belajar siswa sangat meningkat pada siklus II yaitu terdapat 29 siswa atau 80,95\% siswa sudah tuntas belajar materi pokok sistem ekonomi melalui penerapan model pembelajaran kooperatif tipe Numbered Head Together (NHT).

Pada siklus II hanya 7 siswa atau 19, 05\% yang tidak tuntas. Penyebab 7 siswa tersebut tidak tuntas dikarenakan pada saat guru menjelaskan materi pelajaran mereka tidak memperhatikan secara baik materi yang disajikan oleh guru, bahkan sebagian dari mereka hanya mengganggu teman, sehingga ketika evaluasi berlangsung mereka tidak dapat menjawab soal dengan baik.

Berdasarkan uraian di atas dapat dikatakan bahwa meningkatkan aktivitas dan prestasi belajar siswa pada materi pokok system ekonomi dapat dilakukan melalui penerapan model pembelajaran kooperatif tipe Numbered Head Together (NHT). Dengan adanya peningkatan aktivitas belajar dari siklus I ke siklus II sebesar 20,83\% dan peningkatan prestasi hasil belajar siswa dari siklus I ke siklus II sebesar 14,28\%, maka dapat dikatakan bahwa model pembelajaran kooperatif tipe Numbered Head Together (NHT) terbukti lebih meningkatkan aktivitas dan prestasi belajar siswa dibandingkan dengan pembelajaran yang mengunakan cara konvensional.

\section{KESIMPULAN}

Berdasarkan uraian di atas, peneliti menyampaikan kesimpulan sebagai berikut: 1) Pembelajaran kooperatif (Cooperative Learning) tipe Numbered Head Together (NHT) dalam ekonomi khususnya materi sistem ekonomi telah memotivasi siswa untuk lebih aktif, kreatif, inovatif, mandiri dan bekerjasama. Hal ini dibuktikan dengan adanya peningkatan prestasi hasil belajar siswa dari siklus I ke siklus II sebesar 14,28\%. 2) Pelaksanaan pembelajaran kooperatif (Cooperative Learning) tipe Numbered Head Together (NHT) dapat meningkatkan prestasi belajar ekonomi materi sistem ekonomi pada siswa kelas X IPS 3 SMA Negeri 3 Tebo tahun pelajaran 2019/2020. Hal ini dibuktikan dengan adanya peningkatan aktivitas belajar dari siklus I ke siklus II sebesar $20,83 \%$.

\section{DAFTAR PUSTAKA}

Dewi, D. R., \& Prihandono, T. (2017). Penerapan Model Pembelajaran Kooperatif Tipe Number Head Together (Nht) Disertai Metode Eksperimen Pada Pembelajaran Fisika Kelas X di SMA Negeri Arjasa. Jurnal Pembelajaran Fisika, 5(1), 47-52. 
Hasibuan, A. A., Syah, D., \& Marzuki, M. (2018). Manajemen Pendidikan Karakter di SMA. Tarbawi: Jurnal Keilmuan Manajemen Pendidikan, 4(02), 191-212.

Indraswati, D. I. (2018). Efektivitas Model Pembelajaran Kooperatif Tipe Numbered Heads Together (NHT) Terhadap: Kompetensi Sikap Siswa, Kompetensi Pengetahuan Siswa, Dan Kompetensi Keterampilan Siswa Pada Pelajaran Ekonomi Di Kelas X Di SMA N 1 Sentolo. Journal Research and Analysis: Economy, 1(2), 52-58.

Lagur, D. S., Makur, A. P., \& Ramda, A. H. (2018). Pengaruh Model Pembelajaran Kooperatif Tipe Numbered Head Together (NHT) terhadap Kemampuan Komunikasi Matematis. Mosharafa: Jurnal Pendidikan Matematika, 7(3), 357-368.

Manizar, E. (2015). Peran guru sebagai motivator dalam belajar. Tadrib, 1(2), 204-222.

Mastika, I. N., Arnyana, I. B. P., \& Setiawan, I. G. A. N. (2014). Analisis standarisasi laboratorium biologi dalam proses pembelajaran di SMA Negeri Kota Denpasar. Jurnal Pendidikan dan Pembelajaran IPA Indonesia, 4(1).

Purnomo, B. E., Sinon, I. L., Yusuf, I., \& Widyaningsih, S. W. (2017). Penerapan model kooperatif tipe nht untuk meningkatkan partisipasi dan prestasi belajar fisika. Sainsmat: Jurnal Ilmiah Ilmu Pengetahuan Alam, 6(1), 67-74.

Rofiqoh, F., Mahardika, I. K., \& Yushardi, Y. (2015). Pengaruh model pembelajaran kooperatif tipe numbered heads together (NHT) disertai media monopoli games terintegrasi pendekatan problem solving pada pembelajaran fisika di SMA. Jurnal Pembelajaran Fisika, 4(3), 198-203.

Seknun, M. Y. (2018). Kedudukan Guru Sebagai Pendidik. Lentera Pendidikan: Jurnal Ilmu Tarbiyah dan Keguruan, 15(1), 120-131.

Sofyan, Y., \& Agustang, A. (2018). PENERAPAN MODEL PEMBELAJARAN KOOPERATIF TIPE NHT (NUMBERED HEADS TOGETHER) TERHADAP KEAKTIFAN BELAJAR SISWA KELAS XI IPS 1 SMAN 8 MAKASSAR. Jurnal Sosialisasi: Jurnal Hasil Pemikiran, Penelitian dan Pengembangan Keilmuan Sosiologi Pendidikan, 158-165.

Sudarsana, I. K. (2018). Pengaruh model pembelajaran kooperatif terhadap peningkatan mutu hasil belajar siswa. Jurnal Penjaminan Mutu, 4(1), 20-31.

Susilo, A., Siswandari, S., \& Bandi, B. (2016). Pengembangan Modul Berbasis Pembelajaran Saintifik Untuk Peningkatan Kemampuan Mencipta Siswa Dalam Proses Pembelajaran Akuntansi Siswa Kelas XII SMA NI Slogohimo 2014. Jurnal Pendidikan Ilmu Sosial, 26(1), 50-56. 